Michael E. Drew

\title{
The Puzzle of Financial Reporting and Corporate Short-Termism: A Universal Ownership Perspective
}

\section{Correspondence}

Professor Michael E. Drew, Department of Accounting, Finance and Economics, Griffith Business School, Griffith University. Tel: +07 373

55311; fax: 07373 53719; email: michael.drew@griffith.edu.au

This study considers the controversy surrounding financial reporting and corporate short-termism as a puzzle. The question remains as to why corporate managers and investors persist in exhibiting behaviours that trade off long-term value creation for meeting short-term financial targets. Using inter-temporal choice theory, we suggest that the myopia characterising decision-making is entirely rational, given the set of incentives faced. We view the puzzle through the prism of universal owners (pension and superannuation funds), arguing that the investment policies or 'mandates' implemented by these financial behemoths is the source of the myopic behaviour. The paper explores a range of policies that universal owners may consider implementing to ensure that the payoffs to corporate managers and investors are optimised through the pursuit of long-termism. 


\section{On short-termism}

... the role of management should not be beating abstract numeric estimates but improving the operations and long-term prospects of organizations. Jack Bogle, Founder, The Vanguard Group Inc.

There is little doubt that research into the linkages between financial reporting and corporate short-termism have been voluminous and captured the imagination of practitioners, regulators and academics alike. ${ }^{1}$ The short-termism or 'myopia' puzzle might be framed starkly as a problem of inter-temporal choice. And, as with all controversial intertemporal choice decisions, optimising short-term objectives (say, meeting or exceeding quarterly earnings targets) may be made at the expense of long-term payoffs (say, five-year shareholder value creation). This study explores the behaviour of corporate managers and investors to ascertain the rationality (or otherwise) of the inter-temporal choices being made, arguing that the current payoffs to short-termism dwarf those for any other timeframe. To advance the debate, we examine the influence that universal owners (pension and superannuation funds) have on current behaviours, finding that the investment policies or 'mandates' adopted by these institutions perpetuate the cycle of myopia. Finally, we consider various policy paths that universal owners may adopt to enhance the payoffs to long-termism. $^{2}$

\section{Corporate Owners and Investors}


The setting of time horizons is central to understanding how intertemporal choices are made (Mosakowski and Earley 2000). Researchers in the field of financial reporting and corporate short-termism tend to focus on two principal actors when considering the setting of time horizons: corporate managers and investors. As will be discussed below, recent survey-based work regarding these two cohorts strongly suggests that short-termism is alive and well.

We commence our discussion by considering the behaviour of corporate managers. In this study, we define corporate managers as chief executive officers (CEOs) and chief financial officers (CFOs) of large market capitalisation, publicly listed companies. In a much cited survey of more than 400 corporate managers, Graham, Harvey and Rajgopal (2005) found that almost four out of every five respondents indicated that they would decrease discretionary spending on such areas as research and development, advertising, maintenance and hiring in order to meet shortterm earnings targets. More than half of the respondents said they would delay new projects, even if it meant sacrifices in value creation. One of Graham et al.'s (2005) most telling findings relates to the way corporate managers view the rationality of their inter-temporal choices, finding that most feel they are making an 'appropriate choice' when sacrificing longterm value creation to smooth earnings or to hit a quarterly target, as the 
turmoil that can result in equity and debt markets from a negative earnings surprise can be costly (at least in the short run). In conclusion, Graham et al. (2005) hypothesise that given the reality of severe market (over-) reactions to earnings misses, corporate managers might be making the optimal choice in the existing equilibrium. This conclusion is further supported by the ground-breaking work of Debondt and Thaler (1985) that documents the behavioural bias of over- and under-reaction in stock markets by investors.

Given the evidence suggesting that the payoffs to short-termism are greater than the alternative, it is important to consider whether these views are reflected by the boards of listed companies. Do boards reinforce short-termism by, say, reacting negatively to missing short-term earnings expectations? A recent study by Mergenthaler, Rajgopal and Srinivasan (2009) provides evidence supporting the idea that boards of listed companies reinforce myopic behaviour. From a sample of thousands of corporate managers (CEOs and CFOs) of US-listed companies for the decade to 2004, Mergenthaler et al. (2009) find that missing quarterly earnings benchmarks is associated with career penalties in the form of reduced bonuses, smaller equity grants and a heightened probability of forced dismissal for CEOs and CFOs. The findings of Mergenthaler et al. (2009) suggest that boards appear to react directly to 
managers' ability to meet earnings targets or to the information that is reflected in meeting such benchmarks.

The work of Graham et al. (2005) posits exogenous reasons (such as negative reaction to poor short-term performance), while the work of Mergenthaler et al. (2009) outlines a more endogenous rationale (negative board reaction in the form of heightened career risk) for the short-termism exhibited by corporate managers. Regardless of the source of the incentives, the evidence presented seems to corroborate the notion that, given the incentives faced by corporate managers, an inter-temporal choice that views the payoffs of meeting short-term performance goals over long-term value creation is optimal.

One of the uniting themes to come from the work of Graham et al. (2005) and Mergenthaler et al. (2009) relates to the detrimental consequences (particularly relating to the cost of capital) that a firm faces by missing short-term earnings targets. This provides a useful segue to the second major cohort investigated by researchers in the short-termism debate - the investors. Investors in this study are defined as being wholesale in nature - mutual funds and the wider investment management industry. This cohort appears to have an almost insatiable appetite for information on the future earnings prospects of listed companies. The Graham et al. 
(2005) study noted that corporate managers believed earnings, not cash flows, is the key metric considered by investors. Earnings information, particularly forward-looking information in the form of 'earnings guidance', plays a vital informational link between corporate managers and investors. To provide a sense of just how central short-term earnings information is to investors, McKinsey and Company (2006) surveyed a worldwide group of corporate managers and identified the three most significant benefits of issuing earnings guidance as: (1) satisfying requests from investors; (2) maintaining a channel of communication with investors; and (3) intensifying management's focus on achieving financial targets.

One of the immediate challenges that myopic investor behaviour creates is that many companies today encounter significant short-term pressures from a more transient investor base (CFA Institute 2006). The annual turnover (popularly termed the ‘churn rate') for shares of New York Stock Exchange (NYSE)-listed companies has changed dramatically over the last half century. For the 15-year period to 1988, the average annual turnover was $40 \%$, increasing to an average of $70 \%$ for the subsequent 15-year period to 2003 (NYSE, 2008). In the five years to 2003, investors churned or 'turned over' their entire portfolio holdings annually, with a 105\% turnover rate recorded in 2002 (NYSE, 2008). ${ }^{3}$ Equity fund 
portfolio turnover rates in the 1950s and 1960s were in the range of 14 to 25\% (Bogle 2005).

The 'transient' theme is echoed in studies considering the inflows and outflows for one very important segment of the investor group: mutual funds. The work of Sirri and Tufano (1998) and Zheng (1999) report that unit holders chase 'hot' funds; that is, the past performance of a mutual fund explains future money flows in and out of the fund. Jin (2005) extends the previous work by looking at mutual fund holdings and returns by creating measures of investor short-termism, finding that flow-toperformance sensitivity is positively correlated with turnover and negatively correlated with the average remaining holding periods of fund investments. ${ }^{4}$ The study contends that short-termism has increased over the past 40 years, showing that mutual fund short-termism is caused by the unit holders' short horizon, but not the other way round (Li 2005). As the vast majority of mutual funds are remunerated as a percentage of funds under management (FUM), outflows from the fund are detrimental to profitability. Hence, once again, we posit that the optimal path for investors is to focus on short-term investment outcomes to ensure the retention of FUM and, hence, profit maximisation. 
The previous discussion leads us to conclude that the short-termism demonstrated by corporate managers and investors is akin to a ‘cooperative’ game, where the optimal outcome for the two players (that is, where payoffs are jointly maximised) is achieved by setting time horizons to the short term (say, a time period of three months to a year). It is important, however, at this point in the discussion to take umbrage with the use of the term optimal. While myopia may be 'optimal' for corporate managers and investors, it is vital to consider the broader implications of this behaviour. Laverty (1996) observes that something has 'broken down' in capitalist economies; firms are either unwilling (or unable) to make investments that are necessary for the future that require a sacrifice of short-term profits. Perhaps the most compelling claim is that systemic short-termism raises the spectre of economic decline (Laverty 1996). Why does this myopic behaviour persist? Why do the payoffs to shorttermism dominate all other timeframes? We turn to the theory of intertemporal choice to provide some positive insights to these most important questions.

As discussed previously, inter-temporal choice is a characteristic of decisions in which the timing of costs and benefits are spread out over time (Loewenstein and Thaler 1989). To explore the issue of timing further, we attempt to visualise the financial reporting and corporate 
short-termism puzzle in Figure 1. Applying Laverty’s (1996) production technologies example to the current debate, a decision must be made between two courses of action: one leads to, say, maximising earnings outcomes in the short term, and the other provides greater value creation over the long term. It is assumed that the short-termism path (represented by the curve labelled $A$ ) reflects, in a stylised form, current practice.

Meanwhile, the second path (represented by the curve labelled $B$ ) requires the firm making a substantial up-front investment. In our example, pursuing $A$ rather than $B$ produces a greater net return at any point in time through to the date labelled $t^{*}$. Beyond $t^{*}, B$ provides greater net returns. ${ }^{5}$

Figure 1 A stylised inter-temporal choice problem

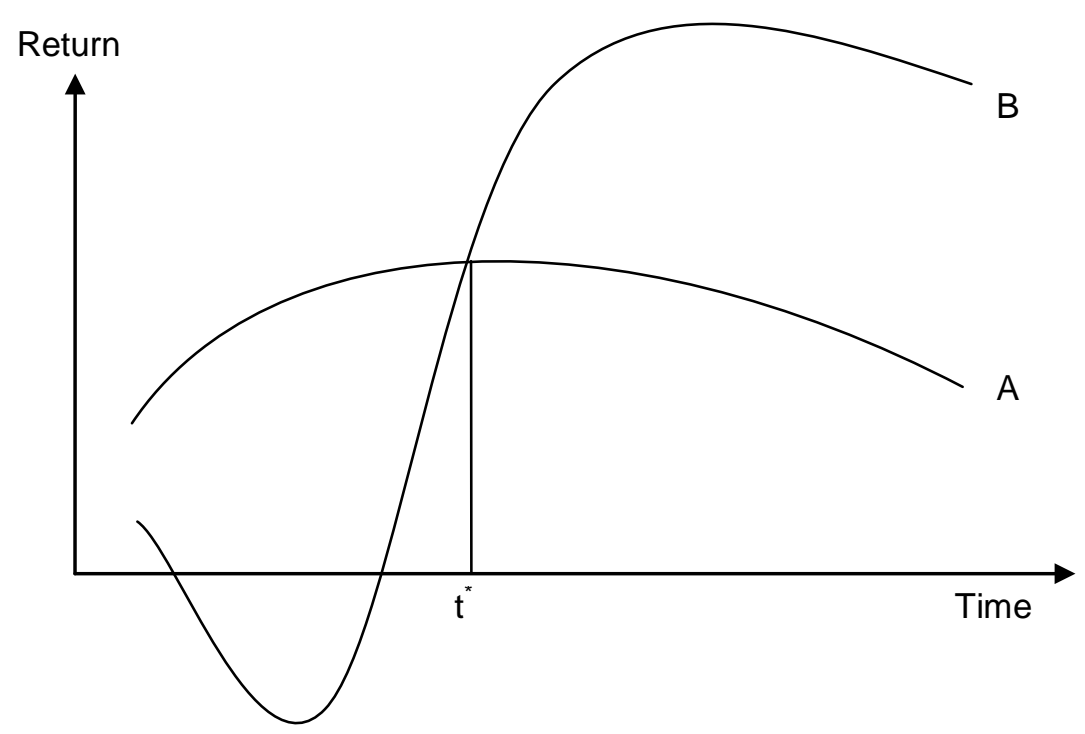

One of the conclusions that may be drawn from Figure 1 relates to the potential externalities that result from corporate managers and investors 
operating at $t^{*}$. The opportunity forgone by not striving for path B is of material concern to the key participants in the short-termism puzzle and society as a whole.

We suggest that a complex system of short-term signals has led to shortterm trading decisions to be made by investors, thereby creating a framework of short-term incentives for corporate managers (both endogenous and exogenous to the firm), or, the 'perfect myopic storm'. The rational response for agents is to move along curve $A$ in our stylised example up to the point $t^{*}$, as, in the current setting, the payoffs to curve $B$ are illusory. The payoffs to myopic behaviour are so pervasive that any potential long-term payoffs beyond $t^{*}$ are discounted to zero. This leads us to ask, who sends the short-term 'signals' to the investor group? What is the source of the myopia?

For one group of participants in the capital markets, the very efficacy of their decisions can only be evaluated in the long term. The fiduciaries of pension and superannuation funds are responsible for making intertemporal choices where the payoff or 'quality' of such decisions may not be known for up to 40 years (the duration of a person's working life). Unlike the timeframes exhibited by corporate managers and investors, the members of pension funds (and ultimately, their fiduciaries) have more 
incentive than most to ensure that all efforts are made to reap the benefits of path $B$. We move the discussion to formally introduce pension and superannuation funds or 'universal owners' as a third cohort entwined in the short-termism puzzle, arguing that this group is the source of shorttermism signals to the capital markets resulting in time horizons being constrained to $t^{*}$.

\section{The Rise of Fiduciary Capitalism and Universal Ownership}

Universal ownership relates to the concentration of equity holdings by 'fiduciary institutions' ${ }^{6}$ These institutions, predominantly pension and superannuation funds, were designed as vehicles whose purpose was to efficiently and effectively transform retirement savings into retirement income. ${ }^{7}$ The rise of fiduciary capitalisation, a term coined by Hawley and Williams (2000), see the fiduciaries of pension and superannuation funds bound to their members by the duty of loyalty and the duty of care. ${ }^{8}$ Universal owners have the ideas of fiduciary capitalism at their very core. It is common for a universal owner, such as a large pension fund, to own up to 5000 different listed companies in their portfolio. In effect, universal owners 'own' the economy. Hence, issues of financial reporting and corporate short-termism become paramount, as these equity holdings typically represent the 'growth driver' of the portfolio. As Monks (2001) neatly summarises, nothing is external to a global shareowner. 
To provide a sense of the scale of the universal owner group, international asset consulting group Watson Wyatt (2008) have estimated that, as at December 2007, the assets of the world's largest 300 pension funds exceeded US\$12 trillion (see Table 1$).{ }^{9}$ Hawley and Williams (2000) note that fiduciary capitalism is typified by highly diversified equity exposures that account for the majority of total portfolio holdings. Importantly for the short-termism puzzle, holdings are, in fact, concentrated in the hands of a relatively small number of the very largest universal owner institutions. ${ }^{10}$ For instance, the 100 largest US fiduciary institutions hold fully 52\% of all publicly held equity (Bogle 2005). A similar concentration of ownership is found in the UK and Australia.

Table 1 Top 20 pension/superannuation funds globally, December 2007

\begin{tabular}{|c|c|c|c|}
\hline Rank & Organisation & Country & $\begin{array}{c}\text { Total assets (US\$ } \\
\text { bn) }\end{array}$ \\
\hline 1 & $\begin{array}{l}\text { Government Pension } \\
\text { Investment }\end{array}$ & Japan & $\$ 1072429$ \\
\hline 2 & Government Pension & Norway & $\$ 370985$ \\
\hline 3 & National Pension & Korea & $\$ 231966$ \\
\hline 4 & Postal Savings Fund & Taiwan & $\$ 129397$ \\
\hline 5 & Canada Pension & Canada & $\$ 123903$ \\
\hline 6 & GEPF & South Africa & $\$ 103644$ \\
\hline 7 & Central Provident Fund & Singapore & $\$ 94964$ \\
\hline 8 & Employees Provident Fund & Malaysia & $\$ 94659$ \\
\hline 9 & National Social Security & China & $\$ 70731$ \\
\hline 10 & Fondo de Reserva Seguridad & Spain & $\$ 66504$ \\
\hline 11 & FRR & France & $\$ 49973$ \\
\hline 12 & Future Fund & Australia & $\$ 44354$ \\
\hline
\end{tabular}




\begin{tabular}{lcll}
13 & Employees’ Provident & India & $\$ 43116$ \\
14 & Local Government Pensions & Finland & $\$ 35278$ \\
15 & AP Fonden 3 & Sweden & $\$ 34765$ \\
16 & AP Fonden 2 & Sweden & $\$ 34503$ \\
17 & AP Fonden 1 & Sweden & $\$ 33423$ \\
18 & AP Fonden 4 & Sweden & $\$ 31562$ \\
19 & National Pensions Reserve & Ireland & $\$ 30847$ \\
20 & Zilverfond & Belgium & $\$ 22594$ \\
\hline
\end{tabular}

Source: Watson Wyatt (2008).

The work of Hawley and Williams (2000) and Monks (2001) provides a useful starting point for a ‘universal ownership' perspective to be brought to bear on the financial reporting and short-termism puzzle. To understand the puzzle is to identify the source of the signals flowing to the investment community and, ultimately, corporate managers. It is the universal owners who set the mandates or 'rules' by which members' retirement savings are managed. The study now turns to a discussion of the potential for universal investors to move the time perspective from short-termism to long-termism; that is, $t>t^{*}$.

\section{Universal owners and Long-termism}

One of the major benefits of the universal owner paradigm is that that there are relatively few, easy identifiable owners of all the listed companies in the world (Gjessing and Syse 2007). In this section, we explore the possibility of shifting the pendulum towards long-term performance and value creation by listed companies (that is, emphasising 
value creation at the expense of short-term results) by considering the mandates that universal owners may implement as a catalyst for change. We make no claims that the following section provides a definitive course to resolve the short-termism puzzle, but forward a set of ideas or principles that may be adopted by universal owners to minimise the externalities resulting from current practice. Regardless of the merits of the ideas canvassed in this section, our central hypothesis is that any change to financial reporting regulations designed to minimise the practice of short-termism will be futile without the universal owner cohort providing incentives for corporate managers and investors that result in the payoffs to long-termism being optimal.

The immediate challenge is the seeming disconnect between the longterm investment horizons of members and the myopic investment policies or 'mandates' issued by universal owners to mutual funds and the broader investment management community. Blake (1995) has criticised pension and superannuation funds as having an obsession for generating shortterm investment returns whatever the longer term costs. Most mandates issued by pension funds have three-year rolling performance objectives and are evaluated quarterly (Hewitt, Bacon and Woodrow 2004). Performance-related fees paid by universal owners to the investment management industry tend to be on the basis of index out-performance 
and peer relativity, again with an emphasis on quarterly evaluation and annual payment. It is argued that the relatively short timeframes used by universal owners to reward the performance of their investment managers has had a cascading effect from universal owners through to investors and ultimately to corporate managers. Linking the analysis to the previous discussion, we hypothesise that universal owners are the 'source' of the myopic signal.

The frustration with the status quo led the UK consulting firm Hewitt, Bacon and Woodrow and the Universities Superannuation Scheme Limited in 2003 to launch a public competition entitled 'Managing Pension Fund Assets as if the Long-Term Really Did Matter’. ${ }^{11}$ The competition invited tenders to design and manage a ‘mock' €30 billion pension fund. Among other things, the competition sought answers to the following two questions:

1. Does the organisational structure employed by the universal owner reflect the members' time horizon of at least 20 years?

2. Does the universal owner employ incentives for firms to act responsibly and encouraging others to continually strive to best practice standards? It is important to note that 'firms' refers to both 'corporate managers' (the companies they invest in) and 'investors' 
(the mutual funds and investment managers that implement the mandates issued by the universal owner).

It is argued that the answers to these questions provide potentially important directions for the future of the short-termism puzzle. Prior to canvassing the wide range of mandate directions for universal owners to consider, it is important to link these ideas to the previous discussion. The issues canvassed in this section all relate to the key variable in solving problems of inter-temporal choice, the selection of a time horizon. We regard each of the paths discussed below as acting as a catalyst in skewing the magnitude of payoffs toward long-termism.

A summary of the submissions is provided in Hewitt, Bacon and Woodrow (2004). We have taken these summary results (and the submissions of the eight short-listed entries: Bevans 2003, Heller 2003, Henderson Global Investors 2003, Hodges 2003, Prentice 2003, Schroder Investment Management 2003, Sustainable Forest Systems 2003 and Webster 2003) to provide a list of nine themes that universal owners may consider in formulating mandates to engender long-termism by their investment managers (that is, the investors who operationalise and execute the mandate) and, ultimately, corporate managers. ${ }^{12}$ The potential paths have been clustered into two board areas relating to: ensuring that 
the organisational structure of universal owners is founded on long-term

horizons, and encouraging universal owners to employ a set of incentives

for corporate managers and investors that engender long-termism.

Table 2 Potential paths to long-termism

\begin{tabular}{|c|c|}
\hline Issue & Challenges for universal owners \\
\hline \multicolumn{2}{|r|}{ Panel A: Time horizon } \\
\hline $\begin{array}{l}\text { Long- } \\
\text { term } \\
\text { framewor } \\
\text { ks }\end{array}$ & $\begin{array}{l}\text { Given a minimum time horizon of } 25 \text { years, do the objectives of the } \\
\text { mandate truly reflect members' concerns? } \\
\text { Rather than traditional benchmarks and performance objectives, a set of } \\
\text { principles and guidelines for the management of the fund may include: } \\
\text { preserving the members' contributions and increasing the members' } \\
\text { returns over the long term. }\end{array}$ \\
\hline $\begin{array}{l}\text { Benchmar } \\
\text { ks }\end{array}$ & $\begin{array}{l}\text { Are the benchmarks selected aligned with the expectations of members? } \\
\text { The fund may consider a number of different long-term benchmarks, } \\
\text { with absolute return and inflation-linked approaches as the centrepiece. }\end{array}$ \\
\hline $\begin{array}{l}\text { Restrictio } \\
\text { ns on } \\
\text { short- } \\
\text { term } \\
\text { behaviour }\end{array}$ & $\begin{array}{l}\text { Does the fund have formal policies to penalise undesirable short-term } \\
\text { activities? } \\
\text { A turnover limit may be considered to restrict sales and purchases in the } \\
\text { portfolio to a value of no greater than } 100 \% \text { of the portfolio over a } \\
\text { rolling three-year period. This limit may be implemented by offsetting } \\
\text { any trading costs involved in sales and purchases in excess of this limit } \\
\text { against the investment manager's fees. The manager would not be } \\
\text { stopped from making the trade if a particularly good opportunity arose. }\end{array}$ \\
\hline $\begin{array}{l}\text { Manager } \\
\text { monitorin } \\
\text { g }\end{array}$ & $\begin{array}{l}\text { Does the fund monitor the holding period of investments and question } \\
\text { the investment manager if any were held for less than five years? } \\
\text { Due to transaction costs, short-term investment bubbles, and the slow } \\
\text { investment process necessary to gain market exposure for large funds, it } \\
\text { is suggested that investment managers should only invest in holdings } \\
\text { they planned to keep for the long term. This perspective is also accretive } \\
\text { from an after-tax management perspective. }\end{array}$ \\
\hline $\begin{array}{l}\text { Split fees } \\
\text { calculatio } \\
\text { n }\end{array}$ & $\begin{array}{l}\text { Has the fund implemented a reward system to align the interests of the } \\
\text { fund manager(s) and the consortium by using a split fee structure? } \\
\text { The fee agreement may include both a fixed management fee and a } \\
\text { performance fee. In order to move the focus onto a longer term } \\
\text { performance horizon, the performance fee may be based on a rolling } \\
\text { five-year performance, adjusted by the level of volatility achieved over } \\
\text { the fee period. A related idea may involve a segregated fee account } \\
\text { mechanism where the first part of the fee would pay the basic running } \\
\text { costs of the manager on a quarterly basis, and the second performance- } \\
\text { related part would be based on long-term out-performance criteria. }\end{array}$ \\
\hline \multicolumn{2}{|r|}{ Panel B: Incentives } \\
\hline Salaries & Are salaries directly linked to the long-term objectives of the mandate? \\
\hline
\end{tabular}




\begin{tabular}{|l|l|}
\hline $\begin{array}{l}\text { plus } \\
\text { outcome- } \\
\text { related } \\
\text { pay }\end{array}$ & $\begin{array}{l}\text { Remunerating investment managers could be based on fixed salaries set } \\
\text { at levels equivalent to other corporate managers. Through achieving } \\
\text { good returns, the managers would receive incentives but would earn } \\
\text { penalties for poor returns. One possible suggestion is rewards for } \\
\text { absolute returns above 10\% and penalties for returns below 5\% over a } \\
\text { rolling five-year basis. }\end{array}$ \\
\hline $\begin{array}{l}\text { Shares in } \\
\text { the fund }\end{array}$ & $\begin{array}{l}\text { Are investment managers thinking (and acting) like equity holders? } \\
\text { Funds may consider rewarding investment managers with shares in the } \\
\text { fund they were managing. These shares would be locked up for a period } \\
\text { of time (say, a minimum of five years) so that the remuneration is } \\
\text { directly aligned to the performance. Investment managers may be } \\
\text { required to hold their personal retirement savings with the fund. }\end{array}$ \\
\hline $\begin{array}{l}\text { Deferred } \\
\text { bonuses }\end{array}$ & $\begin{array}{l}\text { Is the timing of performance-related fees directly linked to long-term } \\
\text { performance? } \\
\text { The timing (rather than the amount) of the performance-related fees to } \\
\text { investment managers is critical. The fund may consider delaying } \\
\text { bonuses to encourage a long-term perspective on transactions. } \\
\text { Investment managers would still be remunerated in line with market } \\
\text { rates, but their bonuses would be paid five years later, when the } \\
\text { medium-term impact of their investment decisions would be clearer. }\end{array}$ \\
\hline
\end{tabular}

Source: Bevans (2003); Heller (2003); Henderson Global Investors (2003); Hodges (2003); Prentice (2003); Schroder Investment Management (2003); Sustainable Forest Systems (2003); Webster (2003); and Hewitt, Bacon and Woodrow (2004).

The ideas presented in Table 2 are confronting in light of current practice and would require, in many instances, a radical re-think and organisational restructure of both the universal owners themselves and their agents (that is, the mutual funds and wider investment management industry engaged by universal owners). However, we suggest that the 'silver-lining' in this story is in the very nature of fiduciary capitalism. It would only take the fiduciary boards of the world's largest 300 pension funds to change the 'rules of the game' (the mandate) by which the investment management industry plays by to effect meaningful (\$US 12 trillion) change. Even if only the 20 largest pension funds moved their 
mandates to reward long-termism, around US\$3 trillion in FUM, the impact would be substantial.

While not the emphasis of this paper, a point that cannot be emphasised enough in these discussions is the centrality of pension fund members and the impact that myopia has on their final accumulated balance. Members' interests are inherently long term, and the current dislocation between the members' time horizon and the short-termism of universal owners, investors and corporate managers calls into question the ability of universal owners to fulfil their economic obligation of efficiently and effectively transforming retirement savings into retirement income and, ultimately, fulfilling their fiduciary obligation to the membership. The push for long-termism need not preclude or stifle financial innovation (for instance, the rise of hedge funds), as long as they are part of a mandate that is solely focused on maximising the probability that the members' long-term accumulation targets are met.

\section{Conclusion}

Much has been written on the short-termism puzzle. However, the question remains, why does short-termism persist? Why do corporate managers believe they are making an 'appropriate choice' when efforts are focused on achieving short-term results at the expense of long-term 
value creation? Why do investors, particularly mutual funds and the wider investment management community, exhibit such 'transient' behaviour? Under the current 'rules of the game', the mandates set by universal owners (pension and superannuation funds) result in myopic behaviour being optimal. We call on the fiduciaries of pension and superannuation funds globally to review, as a matter of urgency, their current investment policy settings to ensure that mandates are built on the foundation stone of long-termism. Finally, it is vital to acknowledge the heterogeneity of boards and executives of listed companies, investors and universal owners as stakeholders in this debate. While the paper makes no specific comment on the merits (or otherwise) of various forms of industrial organisation, it is hoped that some light has been shed on ensuring that long-term plan member/superannuant welfare is at the heart of the goals of these most important institutions. ${ }^{13}$

Michael E. Drew Ph.D. is Professor of Finance, Discipline Head (Finance and Financial Planning), and Head of Research, Sustainable Enterprise Research Program at the Griffith Business School, Griffith University. He is also a member of the Investment Committee of QSuper, which is one of Australia's largest superannuation funds. The author acknowledges the detailed comments from two anonymous reviewers that provided important feedback on the development of the paper. The contribution of the forum editors, Professor Gerry Gallery (QUT) and Professor Natalie Gallery (QUT), is also gratefully acknowledged. The views expressed in this paper are those of the author and do not necessarily reflect the views of the QSuper Board of Trustees. All errors remain the sole responsibility of the author. 


\section{References}

Bazerman, M. 2005, Judgement in Managerial Decision Making, John Wiley \& Sons, New York.

Bevans, G. 2003, 'Extending Collaboration to Allow Pension Funds Influence Over Major Global Market Players', Submission to Managing Pension Fund Assets as if the Long Term Really Did Matter, Hewitt Bacon and Woodrow/Universities Superannuation Scheme, London, United Kingdom.

Blake, D. 1995, Pension Schemes and Pension Funds in the United Kingdom, Oxford University Press, London.

Bogle, J. 2005, 'The Mutual Fund Industry 60 Years Later: For Better or Worse?', Financial Analysts Journal, 61, 15-24.

CFA Institute 2006, Breaking the Short-Term Cycle, CFA Institute/Business Roundtable Institute for Corporate Ethics, Virginia.

DeBondt, W. and Thaler, R. 1985, 'Does the Stock Market Overreact?', Journal of Finance, 40, 793-805.

Drew, M. and Stanford, J. 2003, 'Principal and Agent Problems in Superannuation Funds', Australian Economic Review, 36, 98-107.

Gjessing, O. and Syse, H. 2007, 'Norwegian Petroleum Wealth and Universal Ownership’, Corporate Governance: An International Review, 15, 427-37.

Graham, J., Harvey, C. and Rajgopal, S. 2005, 'The Economic Implications of Corporate Financial Reporting', Journal of Accounting and Economics, 40, 3-73.

Guyatt, D. 2008, 'How Can Investors Collaborate to Improve the Pension Fund System?', Mercer Investment Consulting. Available at: $<$ http://www.mercer.com/referencecontent.htm?idContent=1310280 $>$.

Hawley, J.P. and Williams, A.T. 2000, The Rise of Fiduciary Capitalism, University of Pennsylvania Press, Philadelphia.

Heller, J. 2003, 'Shared Risks Approach to Responsible Private Equity', Submission to Managing Pension Fund Assets As If The Long Term Really Did Matter, Hewitt Bacon and Woodrow/Universities Superannuation Scheme, London, United Kingdom.

Henderson Global Investors 2003, 'Holistic and Integrated Approach', Submission to Managing Pension Fund Assets As If The Long Term Really Did Matter, Hewitt Bacon and Woodrow/Universities Superannuation Scheme, London, United Kingdom.

Hewitt, Bacon and Woodrow, 2004, Investing Pension Funds as if the Long Term Really Did Matter, Hewitt Bacon and Woodrow/Universities Superannuation Scheme. 
Higson, A. 2003, Corporate Financial Reporting: Theory and Practice, SAGE, New York.

Hodges, P. 2003, 'Influencing and Supporting Good Management in Small to Medium Sized Companies', Submission to Managing Pension Fund Assets As If The Long Term Really Did Matter, Hewitt Bacon and Woodrow/Universities Superannuation Scheme, London, United Kingdom.

Jin, L. 2005, 'How Does Investor Short-Termism Affect Mutual Fund Manager Short-Termism, European Finance Association 2005 Moscow Meetings Paper. Available at: http://ssrn.com/abstract=675262SSRN 675262.

Laverty, K. 1996, 'Economic Short-Termism: The Debate, the Unresolved Issues, and the Implications for Management Practice and Research', Academy of Management Review, 21, 825-60.

Loewenstein, G. and Thaler, R. 1989, 'Anomalies: Intertemporal Choice', Journal of Economic Perspectives, 3, 181-93.

Marginson, D. and McAulay, L. 2008, 'Exploring the Debate on ShortTermism: A Theoretical and Empirical Analysis’, Strategic Management Journal, 29, 273-92.

McKinsey and Company 2006, The McKinsey Quarterly, March. Mergenthaler, R., Rajgopal S. and Srinivasan, S. 2009, 'CEO and CFO Career Penalties to Missing Quarterly Earnings Forecasts'.

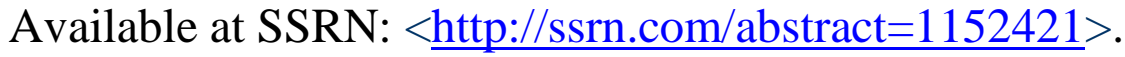

Mosakowski, E. and Earley, P. 2000, 'A Selective Review of Time Assumptions in Strategy Research', Academy of Management Review, 25: 796-812.

Monks, R. 2001, The New Global Investors: How Shareowners Can Unlock Sustainable Prosperity Worldwide, Capstone Publishing Limited, Oxford.

New York Stock Exchange, 2008, Factbook, Available at:

$<$ http://www.nyxdata.com/nysedata/asp/factbook/viewer_edition.asp ?mode=table\&key $=3000 \&$ category $=3>$

Prentice, D. 2003, 'Looking through Prices and Present Values: Matching Asset Cash Flows to Pension Scheme Liability Cash Flows', Submission to Managing Pension Fund Assets As If The Long Term Really Did Matter, Hewitt Bacon and Woodrow/Universities Superannuation Scheme, London, United Kingdom.

Schroder Investment Management 2003, 'Dynamic Asset Allocation for Pension Plans', Submission to Managing Pension Fund Assets As If The Long Term Really Did Matter, Hewitt Bacon and Woodrow/Universities Superannuation Scheme, London, United Kingdom. 
Sirri, E. and Tufano, P. 1998, 'Costly Search and Mutual Fund Flows', Journal of Finance, 53, 1589-622.

Sustainable Forest Systems 2003, 'Developing High-Value Tropical Hardwood to Meet Pension Fund Liabilities', Submission to Managing Pension Fund Assets As If The Long Term Really Did Matter, Hewitt Bacon and Woodrow/Universities Superannuation Scheme, London, United Kingdom.

Watson Wyatt 2008, 'Top Pension Funds Reach Twelve Trillion Dollars', Press Release, 2 September. Available at: $<$ http://www.watsonwyatt.com/news/press.asp?ID=19678>.

Webster, P. 2003, 'How Pension Funds Can Take Responsibility for Influencing their Peers and the Supply Chain', Submission to Managing Pension Fund Assets As If The Long Term Really Did Matter, Hewitt Bacon and Woodrow/Universities Superannuation Scheme, London, United Kingdom.

Zheng, L. 1999, 'Is Money Smart? A Study of Mutual Fund Investors' Fund Selection Ability’, Journal of Finance, 54, 901-933. 


\section{Notes}

${ }^{1}$ Higson (2003) defines short-termism as actions that may be taken today to improve current profit, but at the possible expense of future profits. Short-termism is associated with restricted investment in tangible and intangible assets, following the argument that a preference for short-term performance leads to unintended consequences for the long-term value-adding capability of the firm (Marginson and McAulay 2008).

${ }^{2}$ It is also vital to note at the juncture the centrality of agency theory in framing the inter-temporal choices being made by the various players in the game. As will be seen towards the concluding sections of the paper, trustees are agents to the members of pension funds; investment managers are agents of the trustees; hence the centrality of the incentives set by the trustees (or, 'universal owners') and the important role of principle-and-agent relationships in this puzzle. See Drew and Stanford (2003) for an analysis of principal-and-agent problems in Australia's superannuation arrangements.

${ }^{3}$ In contrast, the CFA Institute (2006) report that a group of Fortune magazine's 2006 Most Admired Companies specifically recognised in the category of 'Long-Term Investment' had an average turnover rate of approximately $60 \%$ in 2005 . These results suggest that instead of short-term shareowners or speculators applying undue pressure, a core base of long-term shareowners allow these companies to make sound long-term investments.

${ }^{4}$ Jin (2005) reports the correlations are statistically significant at the $1 \%$ level.

${ }^{5}$ We acknowledge that one of the most important concerns regarding time involves balancing concerns for long-term positioning, growth and change with concerns for short-term performance, profitability and survival (Laverty 1996). Figure 1 attempts to simply encapsulate, in a visual form, the weight of evidence suggesting that corporate decision-makers and investors are operating at a point along the time continuum such that $t \leq t^{*}$. It is also important to note the returns presented on the $y$-axis are riskadjusted returns and that different agents will vary the level of risk willing to be borne as a function of their utility curve. The other aspect of risk-adjustment that is important for this debate (and the field of valuation generally) is the role of real-options. In the stylised model presented, it is implicit that these options values are fully priced by agents.

${ }^{6}$ It is not uncommon for pension and superannuation funds to hold up to $65 \%$ of their holdings in domestic and international equities. Watson Wyatt (2008) report that, as at January 2008, the average pension fund globally held around $56 \%$ of its portfolio in equities. For a complete update across the asset classes, see $<$ http://www.watsonwyatt.com/news/press.asp?ID=18579 $>$.

${ }^{7}$ Guyatt (2008) of Mercer consulting neatly summaries, ‘... global pension funds collectively represent a powerful group with considerable influence over the financial market system; they are not only large owners of listed (and increasingly private) equity investments, but they also act on behalf of millions of individuals around the world in the management of their long-term savings'.

${ }^{8}$ Monks (2001) makes an important distinction between mutual funds and pension funds, 'in contrast with mutual funds and insurance companies ... pension funds have identifiable beneficiaries - typically individuals who will retire in 25 years with adequate resources and with the intention to live with dignity in a safe, clean, and civil world'.

${ }^{9}$ This compares to total US gross domestic product for 2007 of around US\$13.8 trillion.

${ }^{10}$ The shift from individual to institutional holding of equities has been dramatic. Hawley and Williams (2000) report that as recently as the early 1970s, individuals owned as much as $80 \%$ of US corporate equity, but by the 1990s, individual ownership had fallen to less than half.

${ }^{11}$ For a full report, see Hewitt, Bacon and Woodrow Limited (2004).

${ }^{12}$ A total of 88 entries were made to the competition. The summary report by Hewitt, Bacon and Woodrow (2004) provides the key themes from all entrants, with an emphasis on those short-listed.

${ }^{13}$ We would suggest that future research in further understanding the puzzle may take a lead from Bazerman (2005) and implement an experimental design that would enable the framing of information in the theory posed to be tested explicitly. 